\title{
Az Én Ringatóm, arz én rekreációm
}

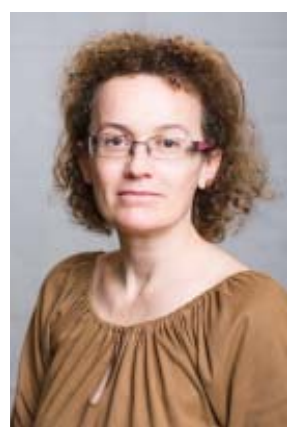

Szerző:

Dr. Patakiné Bösze Júlia

adjunktus

Munkahelye: Eötvös Loránd

Tudományegyetem Egészségfejlesztési

és Sporttudományi Intézet.

1117 Budapest, Bogdánfy u. 10

bosze.julia@ppk.elte.hu

Tudományos tevékenysége:

neveléstudomány

Kutatási területek: életmód,

egészségfejlesztés, szabadidős aktivitások

\section{Összefoglalás:}

\section{A Ringató foglalkozások részben a kisgyermekkori zenei nevelésről szól- nak. A kodályi elvek alapján építkező program azonban a gyermekek mellett a szü- lök "nevelésével" is foglalkozik.}

Írásom célja a program saját élményű bemutatása, illetve ajánlása az óvodáskor alatti gyermeket nevelő családok számára. A Ringató foglalkozások számos állandó helyszínen és egyre növekvő számban alkalmi jelleggel is megtalálhatóak hazánkban, s már a környező országokban is.

A közös, szülő-gyermek programok általános hasznossága mellett itt a zene mint az önkifejezés eszköze segíti a pozitív élmények kibontakozását, s nem mellékesen a múveltség fejlődését.

Javasolható részben kulturális tartalmú foglalkozás az óvodáskor alatti gyermekeknek családi programként, melyek a személyiség több szintjének gazdagítását szolgálják, s a Ringató foglalkozás is ilyen.

Kulcsszavak: családi foglalkozás, éneklés, élmény

\section{Abstract:}

Ringató activities are partly about on early childhood education for music. However roots are based on the principles of Kodály program for children, the parents can be also educated.

The purpose of this study is to present the program by own experience and/or recommend it to children under the age of kindergarten and their families. Ringató activities can be found at several permanent premises, and are also held on a growing number of occasional basis in Hungary and in neighboring countries. In addition to the general usefulness of the common program among children and parents, the music promotes the evolving of the positive experience and the development of literacy as a tool for self-expression.

Partly cultural activities are commendable also for children under the age of kindergarten as a family program, serving the enrichment of the multi- level personalities. Ringató activity functions like that.

Keywords: family activity, singing, experience

\section{Bevezetés}

Jelen cikk mondanivalója több szálon kapcsolódik a szellemi rekreáció tárgyköréhez. Kikapcsolódás, szórakozás a kultúra által nyújtott eszközök egy részével (Kovács, 2004), az ének- léssel és játékkal egybekötve. Szabadidős tevékenység a szülők részvételével, ahol a kisgyermekükkel együtt élvezhetik a nem elsősorban a fizikumot igénybe vevő foglalkozást. Tehát elmondhatjuk, hogy a Ringató foglalkozás a Kovács (2004)-féle besorolás szerint a szellemi rekreációs területen belül a szülők részéről többnyire az aktív alcsoportba tartozik.

A gyermekek részéről a foglalkozás többnyire a szellemi rekreáción belül a passzív alcsoportba kerülhetne, de mindez csak addig igaz, míg csak valóban ölben ülve hallgatják a „szülők kórusát”. Viszont a gyermekek nagy része amint teheti, vagyis képes lesz az önálló helyváltoztató mozgásra, az ölbeli foglalkozás során nem csak hallgató „,tevékenységet végeznek", hanem maguk is énekelni kezdenek, vagy táncolni, s eközben többnyire „útra kelnek”, bejárják a rendelkezésre álló teret, kipróbálják, felfedezik a helyiség tárgyait, s közben vissza-visszatérnek, és újból „ölbeli hallgatóság” válik belőlük. Tehát hol a szellemi rekreáció passzív, hol az aktív alcsoportját valósítják meg.

Ábrahám (2010) a tevékenységek rendszerezését azok fő formai jegyei alapján javasolja, s így a Ringató a kulturális tevékenységek alcsoportjába tartozik mind a szülők, mind a gyermekek részéről. Emellett Ábrahámnál (2010) megjelenik a tevékenységek hierarchizált értékrend alapján való csoportosítás elmélete is. Ezen megközelítés alapján a szülők tekintetében a Ringató a piramis meglehetősen magas szintjén álló, nagy értéktartalommal bíró aktív elfoglaltságok alcsoportjába sorolható be, míg a gyermekek tekintetében részben az érzelmi tevékenységek, részben az aktív tevékenységek csoportjába.

Fritz (2015) besorolása szerint a szellemi rekreáción belül a Ringató részben a kulturális, részben a társasági tevékenységek közé sorolható mind a szülők, mind a gyermekek részéről, hiszen a kultúra, az éneklés a fő eszköz, viszont mondhatjuk, hogy a társas elem is nagymértékben hozzájárul a foglalkozások hangulati és érzelmi összetevőihez.

A program mottója: „Vedd öledbe, ringasd, énekelj!” Számos cikk szól arról, hogy miért jó a ritmus, a zene a kisgyermekeknek (Anvari et al., 2002; Hannon-Johnson, 2005; Zentner-Eurola, 2010; Geist et al., 2012). Amit én szeretnék hangsúlyozni, hogy a szülők is sokat tanulnak, fejlődnek, s közben szórakozás, kikapcsolódás is lehet számukra egy-egy foglalkozás.

\section{Módszerek}

Jelen cikk megírása során két fő forrásra támaszkodtam. Részben ennek a módszernek a kidolgozója által készített honlap információira, részben saját tapasztalataimra. Célom volt egy olyan foglalkozás bemutatása és ismertetése több szempont alapján, melyet bátran ajánlhatok minden óvodáskor alatti gyermekes család részére.

\section{Eredmények}

Számos nem csak budapesti, s már mondhatjuk, nem csak magyarországi helyszínű megjelenés (Ringató_4, é.n.), interjúk sora a média több formájában (Ringató_5, é.n.; Ringató 6, é.n.; Ringató 9, é.n.), kiadványok mint naptár, könyv, $\mathrm{CD}$, füzetke (Ringató_7, é.n.) kapcsolódik a Ringatóhoz, valamint több díj is, mint a Pro Familiis (Ringató_3, é.n.) 
Gállné Gróh Ilona a Ringató módszertani program megálmodója, alapítója (Ringató_2, é.n.), és akik mögötte, de inkább mellette állnak, a nagy-nagy lelkesedéssel és hittel dolgozó foglalkozásvezetők.

A mi foglalkozásvezetőnk Móni. Lassan négy éve ismerem, mert ahogy ezt más családoknál is látom, ha valaki egyszer eljön, jön másodszor és többedszer, s ha az első gyerek „kinövi” a Ringatót, akkor a következő gyerekkel is jön a szülő.

Nem óriásplakátokon vagy fizetett hirdetések útján terjed, hanem a jó gyakorlatok jól működő propagandájával „száll az ének szájról szájra". Természetesen van saját weboldaluk, s a legtöbb foglalkozásvezetőnek saját Ringatós közösségéhez szóló, zárt facebook csoportja is, de ezekre az oldalakra csak úgy jut el az ember, ha már Ringatós lett. Tehát ott a már érdeklődők, kipróbálók juthatnak még több információhoz, oszthatják meg örömeiket egymással.

A többnyire szeptembertől kezdődő (Ringató 1, é.n.), heti rendszerességű foglalkozások mellett aki teheti, ellátogat az alkalmi, a megszokottól eltérő helyszínekre is Ringatózni (Ringató_3, é.n.). Nem árulok el nagy titkot, ha leírom, hogy a foglalkozások népszerúek (Ringató_8, é.n.).
Szülőként kipróbáltam számos kisgyermekprogramot, -foglalkozást. Néhány volt közöttük, ami zenéhez is köthető volt. Azt tapasztaltam, hogy a legalább részben a kodályi hagyományokra épülő, részben népzenének is mondható dallamok jelentették a kisgyermekek számára az egyik legnagyobb élményt.

Ebbe a csoportba sorolható a Ringató is. Minden foglalkozáson megtörténik egy zenei varázslat, „síppal, dobbal, nádi hegedűvel" füszerezve. De ami a kisgyermekes szülőnek fontos, hogy nem csak a gyermeknek szólnak a foglalkozások. Itt a foglalkozásvezető mellett, vagyis még inkább vele együtt a szülők énekelnek a gyermekeiknek, a többieknek és önmaguknak.

Aki nem próbálta, ám van óvodáskor alatti gyermeke, javaslom, keresse meg a honlapjukon található adatbázisból, hol található a hozzá legközelebb eső állandó helyszín, s tegyen egy próbát. Remélem, mindenkinek olyan élményt fog jelenteni, mint azoknak a sokaknak, akik heti rendszerességgel, újra meg újra elmennek énekelni, mondókázni, játszani. Igazi családi program. Itt minden szülő énekel, a foglalkozásvezető előénekel, vagy együtt énekel a szülőkkel. Ez olyan, mint egy kis kórus. A repertoár egyre bővül, a magyar mellett más

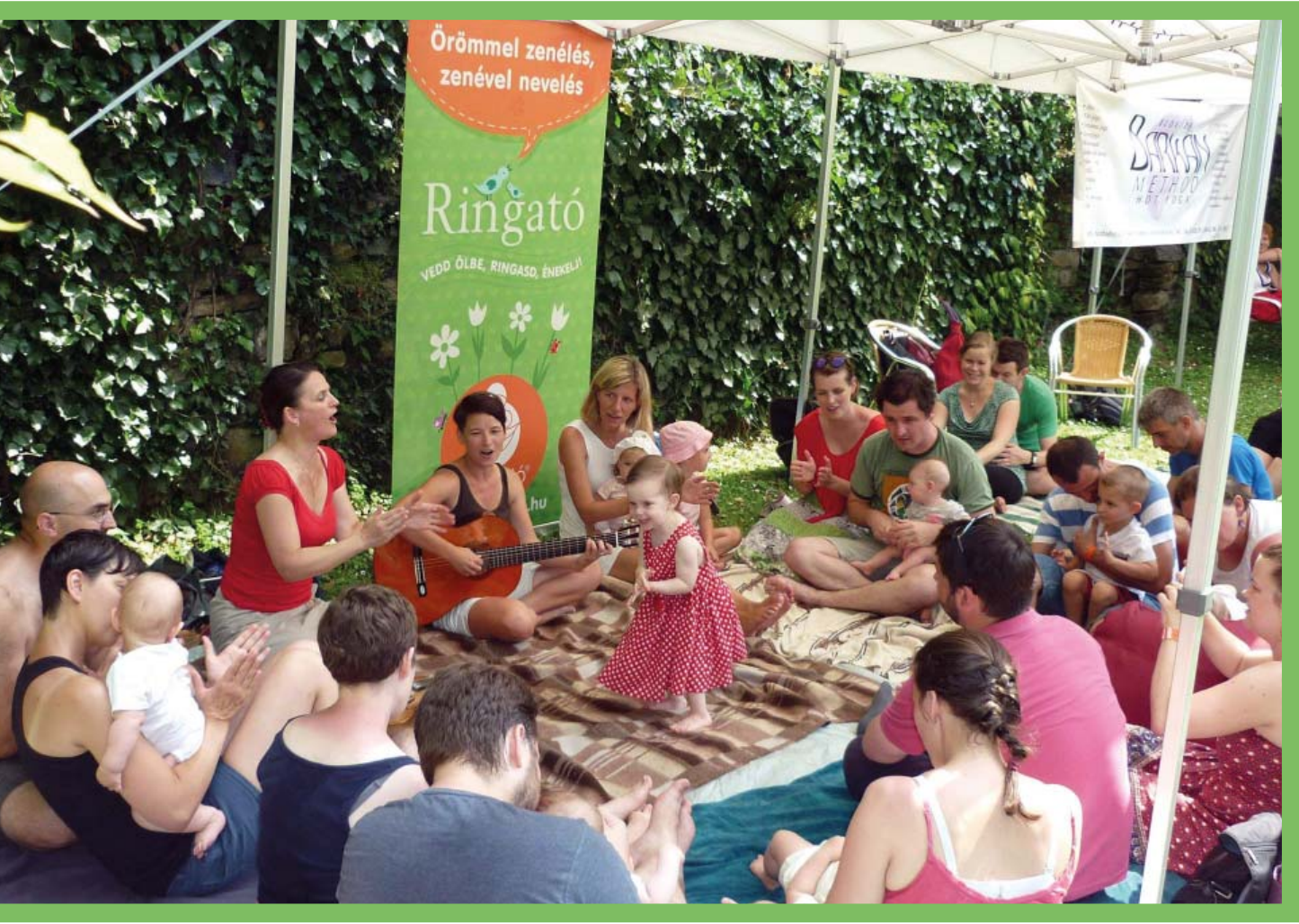
nemzetek népi alapú gyermekdalai is megjelennek, és végül akár hiszi az ember, akár nem, már egy többszólamú dal vagy kánon is megjelenik minden foglalkozáson, s a sikerélmény is megjelenik a néha elbizonytalanodó szülő szemében: „Igen, így kell ezt csinálni".

\section{Következtetések}

Lehetséges, hogy az énekóra nagyon kezd kiszorulni az iskolákból, ám nem igaz, hogy csak a bóvli a népszerü a felnőttek és gyermekek körében. Nálunk már a másfél éves gyerek is énekli: „Így kell járni, úgy kell járni, Sári, Kati tudja, hogy kell járni".

A gyerekek legtöbbször nagyon várják a nyári szünetet. Ez a hely viszont az, ahol fordítva van. Sajnáljuk, hogy szünet van, s várjuk, hogy szeptembertől újra kezdődjön a Mi Ringatónk.

\section{Irodalomjegyzék}

Ábrahám, J. (2010): Rekreációs alapok. NEFM! Sportért felelős Államtitkárság, Budapest

Anvari, S.H. - Trainor, L.J. - Woodside, J., Levy, B.A. (2002): Relations among musical skills, phonological processing, and early reading ability in preschool children. Journal of Experimental Child Psychology. 83. 2. 111-130. doi:10.1016/S00220965(02)00124-8

Fritz, P. (szerk., 2015): Rekreáció mindenkinek II. Szellemi rekreáció. Dialóg Campus, BudapestPécs

Geist, K. - Geist, E.A. - Kuznik, K. (2012): The Patterns of Music: Young Children Learning Mathematics through Beat, Rhythm, and Melody. Young Children. 67. 1. 74-79.

Hannon, E.E. - Johnson, S.P. (2005): Infants use meter to categorize rhythms and melodies: Imp lications for musical structure learning. Cognitive Psychology. 50. 4. 354-377. doi:10.1016/j.cogpsych.2004.09.003

Kovács, T. A. (2004): A rekreáció elmélete és módszertana. Fitness Akadémia. Budapest

Ringató_1 (é.n.): Foglalkozások hírei. From: http://www.ringato.hu/?p=educations\&branduser $=62$

Ringató_2 (é.n.): Gállné Gróh Ilona. From: http://www.ringato.hu/?p=subpage \&pid=2

Ringató_3 (é.n.): Kiemelt híreink. From: http:// www.ringato.hu

Ringató 4 (é.n.): Korábbi híreink. From: http:// www.ringato.hu/?p=newsarchive

Ringató 5 (é.n.): Olvasnivalók. From: http:// www. ringato. $h u / ? p=s u b p a g e \& p i d=5$
Ringató_6 (é.n.): Rádióműsorok. From: http:// www.ringato $\cdot \mathrm{hu} / \mathrm{p} \mathrm{p}=$ subpage $\& \mathrm{pid}=18$

Ringató_7 (é.n.): Ringató kiadványok. http:// www.ringato.hu/?p=subpage \&pid $=43$

Ringató_8 (é.n.): Szülői levelekből. From: http:// www.ringato.hu/?p=subpage \&pid=15

Ringató_9 (é.n.): Televíziófelvételek. From: http://www.ringato.hu/?p=subpage \&pid=17

Trainor, L.J. - Wu, L. - Tsang, C.D. (2004): Longterm memory for music: infants remember tempo and timbre. Developmental Science. 7. 3. 289296. DOI: 10.1111/j.1467-7687.2004.00348.x

Zentner, M. - Eurola, T. (2010): Rhythmic engagement with music in infancy. Proceedings of the National Academy of Sciences of the United States of America. 107. 13. 5768-5773. doi: 10.1073/ pnas. 1000121107 